\title{
Praktik Trademark Squatting Dalam Proses Pendaftaran Merek di Indonesia
}

\author{
Zil Aidi* dan Widya Justitia**
}

\begin{abstract}
Abstrak
Penelitian ini bertujuan untuk mengetahui dan menganalisis mengapa praktik trademark squatting dapat terjadi dalam proses pendaftaran merek di Indonesia dan kendala yang ditemukan dalam proses pendaftara merek beserta cara mengatasinya. Selanjutnya, penelitian ini juga membahas mengenai konsepsi ideal terkait proses pendaftaran merek di Indonesia guna menghindari dan meminimalisasi praktik trademark squatting. Penelitian ini merupakan penelitian kualitatif yang bersifat yuridis empiris dan data yang terkumpul dianalisa dengan metode deskriptif kualitatif. Hasil penelitian menunjukkan bahwa praktik trademark squatting merupakan suatu tindakan mendaftarkan merek milik orang lain yang belum terdaftar, sehingga membuat pemilik merek yang sebenarnya tidak dapat lagi mendaftarkan mereknya. Setelah itu, pelaku menjual sertifikat hak atas merek tersebut kepada pemilik aslinya dengan harga melebihi biaya permohonan pendaftaran merek pada umumnya. Kendala yang ditemui dalam proses pendaftaran merek di Indonesia adalah kurangnya sumber daya manusia dalam menangani jumlah permohonan pendaftaran merek yang mencapai ribuan setiap harinya. Hal ini berdampak pada tidak optimalnya proses pendaftaran merek maupun pengawasan terhadap penggunaan merek. Konsepsi ideal terkait pendaftaran merek di Indonesia yaitu dengan menggagas suatu sistem yang bernama first to file based on use guna mengoptimalisasikan perlindungan pemilik merek, pertimbangan untuk meratifikasi Madrid System juga merupakan salah satu opsi lain untuk mencegah praktik trademark squatting.
\end{abstract}

Kata kunci: first to file system, first to use system, hak merek, pendaftaran merek, trademark squatting.

\section{Trademark Squatting Practice in Trademark Registration Process in Indonesia}

\begin{abstract}
The purpose of this research is to identify and analyze why the practice of trademark squatting could occur in Indonesia's trademark registration process along with the constraints found in the trademark registration process in Indonesia and how to overcome them. Furthermore, it will also discuss the ideal conception related to trademark registration process to avoid and minimize the practice of trademark squatting. This research is an empirical legal research and all data were analyzed with qualitative methods. The results showed that trademark squatting is an act performed by actors (trademark squatters) to file trademarks application owned by others, so that when application registered by the real

PADJADJARAN Jurnal IImu Hukum Volume 3 Nomor 1 Tahun 2016 [ISSN 2460-1543] [e-ISSN 2442-9325]

* Mahasiswa Magister Hukum Bisnis Universitas Gadjah Mada Yogyakarta, Jl. Sosio Justisia, Bulaksumur, Yogyakarta 55281, zil.aidi@mail.ugm.ac.id, S.H (Universitas Gadjah Mada).

** Mahasiswa Magister Kenotariatan Universitas Gadjah Mada Yogyakarta, Jl. Sosio Justisia, Bulaksumur, Yogyakarta 55281,widyajustitia@gmail.com, S.H (Universitas Gadjah Mada).
\end{abstract}


owner is rejected, the trademark squatters will offer the real trademark owners to buy the certificate with unreasonable price. Obstacle encountered in the process of trademark registration in Indonesia is the lack of human resources who handle the application which caused the inspection process to become ineffective. The ideal concept of the trademark registration process can be achieved by initiating first to file based on use system to strengthen protections for trademark owner. The consideration to ratify Madrid System is also one of the proper actions to make Indonesia safe from trademark squatters.

Keywords: first to file system, first to use system, trademark rights, trademark registration, trademark squatting.

\section{A. Pendahuluan}

Dewasa ini kehidupan masyarakat berkembang sebegitu pesatnya. Hal ini terlihat jelas pada semakin tingginya intensitas perdagangan. Semakin tingginya intensitas perdagangan baik pada sektor barang dan jasa secara tidak langsung juga berpengaruh pada ketatnya persaingan antar produk-produk yang sejenis. Salah satu hal yang menarik untuk diamati dari ketatnya persaingan antar produk-produk tersebut adalah terkait dengan merek yang mereka gunakan.

Merek adalah sesuatu (gambar atau nama) yang dapat digunakan untuk mengidentifikasi suatu produk atau perusahaan di pasaran. ${ }^{1}$ Merek sangatlah penting dalam dunia bisnis karena terkait dengan pemasaran suatu produk. Hal ini menjadi wajar karena publik sering mengaitkan suatu image, kualitas atau reputasi barang dan jasa dengan merek tertentu. ${ }^{2}$ Signifikansi suatu merek juga akan berguna bagi konsumen karena merek yang terkenal biasanya memberikan jaminan nilai atau kualitas dari barang. ${ }^{3}$ Sebagai contoh tentulah untuk produk sepeda motor di Indonesia merek Honda sudahlah sangat terkenal kualitasnya dibanding merek lain, sehingga mayoritas konsumen sepeda motor akan lebih percaya dan memilih sepeda motor yang bermerek Honda.

Berdasarkan pemaparan di atas, terlihat betapa pentingnya peranan suatu merek atas suatu produk, maka dari itu mutlak dibutuhkan perlindungan hukum atas merek dagang. Adapun pengaturan mengenai merek yang saat ini berlaku di Indonesia adalah Undang-Undang Nomor 15 Tahun 2001 tentang Merek (UU Merek 2001). Pada Pasal 1 ayat (1) UU Merek, merek didefinisikan sebagai tanda yang berupa gambar, nama, kata, huruf-huruf, angka-angka, susunan warna atau kombinasi dari unsur-unsur tersebut yang memiliki daya pembeda dan digunakan dalam kegiatan perdagangan barang atau jasa.

Pada Pasal 3 UU Merek 2001 didefiniskan hak atas merek sebagai hak khusus yang diberikan pemerintah kepada pemilik merek untuk menggunakan merek

\footnotetext{
Tim Lindsey (et.al), Hak Kekayaan Intelektual Suatu Pengantar, Bandung, Alumni: 2002, hlm. 131.

Ibid.

Suyud Margono, Aspek Hukum Komersialisasi Aset Intelektual, Bandung: Nuansa Aulia, 2009, hlm. 21.
} 
tersebut atau memberikan izin untuk menggunakannya kepada orang lain. Perlindungan atas hak merek memiliki perbedaan dengan perlindungan pada hak cipta. Pada hak cipta perlindungan hukum atasnya seketika muncul dan melekat ketika suatu temuan lahir tanpa harus didaftarkan. Hak merek haruslah didaftarkan terlebih dahulu agar dapat terlindungi atau disebut dengan sistem first to file.

Sistem first to file atas hak merek ini menghasilkan suatu celah hukum dalam proses pendaftaran merek. Terdapat suatu fenomena baru yang bernama trademark squatting. Secara sederhana trademark squatting dapat diartikan sebagai praktik untuk mendaftarkan merek-merek atas produk-produk baik barang atau jasa yang belum terdaftar sebelumnya untuk kemudian memperjualbelikannya kembali kepada pemilik merek sebenarnya. ${ }^{4}$

Praktik trademark squatting pada awalnya terjadi dan berkembang di luar negeri. Adapun korban dari trademark squatting di luar negeri adalah merek-merek terkenal yang sudah terdaftar di negara asalnya namun belum terdaftar di negara tempat trademark squatting terjadi. Salah satu contoh trademark squatting terjadi di negara Tiongkok saat perusahaan teknologi asal Amerika Serikat Apple hendak mendaftarkan merek iPhone. Pendaftaran Apple ditolak dengan alasan telah terlebih dahulu didaftarkan oleh perusahaan lokal Tiongkok. Kasus serupa juga dialami oleh perusahaan asal Amerika Serikat yang terkenal dengan produk kopi berikut gerainya yaitu Starbucks Corporation. Merek Starbucks didaftarkan oleh seorang trademark squatters di Rusia sehingga Starbucks Corporation tidak bisa menggunakan merek dagangnya tersebut di Rusia.

Praktik trademark squatting dilakukan oleh pelaku yang biasa disebut sebagai trademark squatters. Trademark squatters biasanya akan melakukan semacam penelitian di lapangan terkait merek mana yang sudah relatif dikenal oleh publik namun belum terdaftar untuk kemudian mendaftarkan merek tersebut. Setelah merek tersebut terdaftar, trademark squatters akan meminta kompensasi kepada pemilik merek asli karena telah menggunakan merek yang telah lebih dulu trademark squatters daftarkan. Umumnya trademark squatters akan meminta uang melebihi nominal yang ia keluarkan saat mendaftarkan merek dulunya. Jika pemilik merek asli menolak untuk membayar atau memberikan kompensasi maka trademark squatters akan meminta pada pemilik merek asli untuk mengganti merek yang selama ini digunakannya atau jika masih bersikeras untuk menggunakan, trademark squatters mengancam akan menempuh jalur hukum.

Tentunya hal ini sangat merugikan pemilik merek asli. Di satu sisi jika mengikuti keinginan dari trademark squatters maka ia harus mengeluarkan biaya yang cukup

4 Hukum Online, "Trademark Squatting Bertumbuh di Indonesia",

http://www.hukumonline.com/berita/baca/It512c3348ac839/itrademark-squatting-i--bertumbuh-diindonesia, diakses 19 Maret 2015. 
besar, namun jika pemilik merek asli menolak untuk membayar kompensasi pada trademark squatters, ancaman akan mempersoalkan hal ini ke jalur hukum dapat menghantui pemilik merek asli.

Berangkat dari fakta ini maka sangat menarik untuk meneliti mengapa praktik trademark squatting dapat terjadi pada proses pendaftaran merek di Indonesia berikut solusi untuk mencegah dan meminimalisasi praktik ini. Meskipun praktik ini berasal dari luar negeri dan belum marak terjadi di Indonesia, namun potensi akan marak terjadinya praktik trademark squatting terbilang tinggi. Mengingat UU Merek 2001 tidak melarang praktik ini secara tegas dan juga terkait dengan sistem pendaftaran merek yang berlaku di Indonesia adalah first to file. Selain itu, masih minimnya kesadaran pelaku usaha di Indonesia untuk mendaftarkan merek membuat mereka semakin rentan terhadap praktik trademark squatting.

Di sisi lain pembahasan mengenai trademark squatting di Indonesia juga menjadi kian penting mengingat Indonesia tengah gencar-gencarnya meningkatkan kerjasama di bidang investasi dan perdagangan internasional. Tentunya untuk melancarkan hal tersebut dibutuhkan perlindungan dan aturan hukum yang baik dan memadai, tak terkecuali terkait dengan Hak Kekayaan Intelekutal (HKI) dalam hal ini mengenai merek.

\section{B. Sejarah Pengaturan Merek di Indonesia}

Dalam sejarah perundang-undangan merek di Indonesia dapat dicatat bahwa pada masa kolonial Belanda berlaku Reglement Industriele Eigendom (RIE) yang dimuat dalam Stb. 1912 Nomor 545 jo. Stb. 1913 No. 214. Setelah Indonesia merdeka, peraturan ini juga dinyatakan terus berlaku berdasarkan Pasal II Aturan Peralihan Undang-Undang Dasar 1945 (UUD 1945). Ketentuan ini masih terus berlaku hingga akhirnya sampai pada tahun 1961 ketentuan tersebut diganti dengan UndangUndang Nomor 21 Tahun 1961 tentang Merek Perusahaan dan Merek Perniagaan (UU Merek 1961) yang diundangkan pada tanggal 11 Oktober 1961 dan dimuat dalam Lembaran Negara Nomor 290 dan penjelasannya dimuat dalam Tambahan Lembaran Negara Nomor 2341 yang mulai berlaku pada bulan November $1961 .{ }^{5}$

Undang-undang Merek yang baru ini merupakan pengganti dan pembaharuan dari hukum merek yang diatur dalam RIE. Adapun alasan lahirnya UU Merek 1961 sebagaimana tercantum dalam pertimbangan undang-undang ini adalah untuk melindungi khalayak ramai dari tiruan barang-barang yang memakai suatu merek yang sudah dikenalnya sebagai merek barang-barang yang bermutu baik. Selain itu undang-undang ini juga bermaksud untuk melindungi pemakai pertama dari suatu merek atau first to use. Pada UU Merek 1961 dikenal penggolongan barang-barang

H. OK. Saidin, Aspek Hukum Hak Kekayaan Intelektual (Intellectual Property Rights), Jakarta: Raja Grafindo Persada, 2004, hlm. 331. 
dalam 35 kelas yang sejalan dengan klasifikasi internasional berdasarkan persetujuan pendaftaran merek di Nice, Perancis pada tahun 1957 yang diubah di Stockholm tahun 1961 dengan penyesuaian kondisi di Indonesia. ${ }^{6}$

Pada tanggal 28 Agustus 1992 diundangkan Undang-Undang Nomor 19 Tahun 1992 tentang Merek (UU Merek 1992) yang berlaku efektif pada tanggal 1 April 1993. UU Merek 1992 menggantikan UU Merek 1961 dengan melakukan penyempurnaan dan perubahan terhadap hal-hal yang berkaitan dengan merek untuk disesuaikan dengan Paris Convention. ${ }^{7}$

Pada perjalanannya UU Merek 1961 dinilai sudah tidak dapat lagi mengakomodir perkembang zaman yang memposisikan merek menjadi salah satu unsur yang penting dan menentukan bagi proses jual-beli barang. Oleh karena itulah lahir UU Merek 1992. Dibandingkan dengan UU Merek 1961, pada UU Merek 1992 terlihat perbedaan-perbedaan antara lain mengenai lingkup pengaturan merek, perubahan sistem pendaftaran merek, pendaftaran merek, ancaman pidana, dan perlindungan merek terkenal. ${ }^{8}$

Pada tahun 1997, UU Merek 1992 diubah dengan Undang-Undang Nomor 14 Tahun 1997 tentang Perubahan atas Undang-Undang Nomor 19 Tahun 1992 tentang Merek (UU Merek 1997). Perubahan ini merupakan konsekuensi dari diratifikasinya perjanjian internasional mengenai Hak Kekayaan Intelektual yaitu Trade Related Aspects of Intellectual Property Rights (TRIPs) pada World Trade Organization (WTO). Pengaturan terakhir mengenai merek terdapat pada UU Merek 2001. Beberapa perubahan penting pada undang-undang ini adalah seputar penetapan sementara pengadilan, perubahan dari delik biasa menjadi delik aduan, peran pengadilan niaga dalam memutuskan sengketa merek, kemungkinan menggunakan alternatif dalam memutuskan sengketa, dan ketentuan pidana yang diperberat. $^{9}$

Terdapat tiga hal yang menjadi dasar pertimbangan atas diundangkannya UU Merek 2001 yaitu sebagai berikut: ${ }^{10}$

a. Bahwa di dalam era perdagangan global, sejalan dengan konvensi-konvensi internasional yang telah diratifikasi Indonesia, peranan merek menjadi sangat penting, terutama dalam menjaga persaingan usaha yang sehat;

b. Bahwa untuk hal tersebut, diperlukan pengaturan yang memadai tentang merek guna memberikan peningkatan layanan bagi masyarakat; dan

c. Bahwa berdasarkan pertimbangan pada huruf a dan huruf b serta

6 Rachmadi Usman, Hukum Hak atas Kekayaan Intelektual: Perlindungan dan Dimensi Hukumnya di Indonesia, Bandung: Alumni, 2003, hlm. 307.

7 Ibid.

8 Ibid., hlm. 308-310.

9 Asian Law Group Pty Ltd, Hak Kekayaan Intelektual Suatu Pengantar, Bandung: Alumni, 2005, hlm. 132.

10 Rachmadi Usman, Op.cit., hlm. 314. 
memperhatikan pengalaman dalam melaksanakan undang-undang Merek yang ada, dipandang perlu untuk mengganti UU Merek 1992 sebagaimana telah diubah denganu UU Merek 1997.

\section{Ruang Lingkup Hak Atas Merek}

Merek menjadi sangat penting dalam pemasaran suatu produk baik itu barang atau jasa. Merek berfungsi untuk memberikan suatu ciri khas atau pembeda antara produk satu dengan produk lain yang sejenis. Hal ini dapat ditemukan pada Pasal 1 ayat (1) UU Merek 2001 bahwa merek adalah tanda yang berupa gambar, nama, kata, huruf-huruf, angka-angka, susunan warna, atau kombinasi dari unsur-unsur tersebut yang memiliki daya pembeda dan digunakan dalam kegiatan perdagangan barang atau jasa.

Pada UU Merek 2001 juga diatur mengenai jenis-jenis merek, antara lain pada Pasal 1 ayat (2) disebutkan bahwa merek dagang adalah merek yang digunakan pada barang yang diperdagangkan oleh seseorang atau beberapa orang secara bersama-sama atau badan hukum untuk membedakan dengan barang-barang sejenis lainnya. Pengertian merek jasa terdapat pada Pasal 1 ayat (3) UU Merek 2001 sebagaimana disebutkan bahwa merek jasa adalah merek yang digunakan pada jasa yang diperdagangkan oleh seseorang atau beberapa orang secara bersama-sama atau badan hukum untuk membedakan dengan jasa-jasa sejenis lainnya. Selanjutnya pada Pasal 1 ayat (4) UU Merek 2001 juga diatur mengenai merek kolektif. Merek kolektif adalah merek yang digunakan pada barang dan/atau jasa dengan karakteristik yang sama yang diperdagangkan oleh beberapa orang atau badan hukum secara bersama-sama untuk membedakan dengan barang dan/atau jasa sejenis lainnya.

Selain jenis-jenis merek yang disebutkan di atas, terdapat juga satu jenis merek lain yang disebut dengan merek terkenal. Pada UU Merek 2001 tidak diberikan definisi atas merek terkenal. Adapun definisi dari merek terkenal dapat ditemui pada Pasal 1 Keputusan Menteri Menteri Kehakiman Republik Indonesia No. M. 02HC.01 Tahun 1987 tentang Penolakan Permohonan Pendaftaran Merek yang Mempunyai Persamaan dengan Merek Terkenal Milik Orang lain (Kepmen Kehakiman 1987).

Pada Pasal 1 Kepmen Kehakiman 1987 diberikan definisi merek terkenal sebagai merek dagang yang telah lama dikenal dan dipakai di wilayah Indonesia oleh seseorang atau badan untuk jenis barang tertentu. Unsur atau hal yang menjadi penentu utama apakah suatu merek dapat dinyatakan sebagai merek terkenal adalah seberapa lama merek atau produk tersebut dikenal dan dipakai di Indonesia.

Terdapat beberapa alasan yang menjadi pertimbangan dikeluarkannya Kepmen Kehakiman 1987 ini, antara lain:11

11 Casavera, 8 Kasus Sengketa Merek di Indonesia, Yogyakarta: Graha Ilmu 2009, hlm. 29. 
a. Karena pemakaian merek terkenal milik orang lain akan menyesatkan masyarakat tentang asal-usul serta kualitas barang; dan

b. Untuk melindungi masyarakat dari kekeliruan memilih barang yang bermutu baik, maka permohonan pendaftaran merek yang mempunyai persamaan pada pokoknya maupun keseluruhannya dengan merek terkenal milik orang lain akan ditolak dalam Daftar Umum Merek.

Menteri Kehakiman pada tahun 1991 mengeluarkan Surat Keputusan No. M.03HC.02.01 Tahun 1991 mengenai Penolakan Permohonan Pendaftaran Merek Terkenal atau Merek yang Mirip Merek Milik Orang Lain atau Milik Badan Lain (Surat Keputusan 1991). Surat keputusan ini lantas menggantikan kedudukan Kepmen Kehakiman 1987. Adapun tujuan dari dikeluarkannya Surat Keputusan 1991 ini adalah untuk memperluas proteksi merek terkenal hingga mencakup pula barangbarang yang tidak sejenis dan memberikan perlindungan bagi merek terkenal yang digunakan di Indonesia dan/atau di luar negeri. ${ }^{12}$

Meskipun pada UU Merek 2001 tidak diatur mengenai definisi merek terkenal, namun undang-undang memberikan perlindungan terhadap merek terkenal sebagaimana tertuang pada Pasal 6 ayat 1 huruf b, yang selengkapnya berbunyi:

"Permohonan harus ditolak oleh Direktorat Jenderal apabila Merek tersebut mempunyai persamaan pada pokoknya atau keseluruhannya dengan merek yang sudah terkenal milik pihak lainnya untuk barang dan/atau jasa sejenis."

Selanjutnya, pada Penjelasan Pasal 6 ayat 1 huruf B UU Merek 2001 disebutkan mengenai kriteria untuk menentukan bahwa suatu merek barang atau jasa sudah masuk dalam kategori merek terkenal, yaitu dilihat dari:

a. Dengan memperhatikan pengetahuan umum masyarakat tentang merek tersebut;

b. Dengan memperhatikan reputasi merek terkenal yang diperoleh karena promosi yang gencar dan besar-besaran; dan

c. Investasi di beberapa negara di dunia yang dilakukan oleh pemiliknya dan disertai bukti pendaftaran merek tersebut di beberapa negara.

\section{Proses Pendaftaran Merek di Indonesia}

UU Merek yang saat ini berlaku di Indonesia menganut sistem first to file. Hal ini berimplikasi pada adanya kewajiban untuk mendaftarkan merek agar merek tersebut dapat terlindungi secara hukum. Pendaftaran merek dimohonkan kepada Direktorat Jenderal (Ditjen) HKI Kementerian Hukum dan Hak Asasi Manusia (Kemenkumham) yang berkedudukan di Jakarta. Pendaftaran ini dapat dilakukan melalui kantor wilayah Kemenkumham yang berada di setiap ibu kota provinsi.

12 Ibid. 
Secara umum sebagaimana diatur dalam UU Merek 2001 terdapat beberapa tahapan dalam proses pendaftaran merek.

Tahapan pertama adalah tahapan administrasi yang dimulai dengan mengajukan permohonan pendaftaran merek secara tertulis dalam bahasa Indonesia kepada Ditjen HKI dengan mencantumkan:

a. tanggal, bulan, dan tahun;

b. nama lengkap, kewarganegaraan, dan alamat pemohon;

c. nama lengkap dan alamat kuasa apabila permohonan diajukan melalui kuasa;

d. warna-warna apabila merek yang dimohonkan pendaftarannya menggunakan unsur-unsur warna; dan

e. nama negara dan tanggal permintaan merek yang pertama kali dalam hal permohonan diajukan dengan hak prioritas. (Pasal 7 UU Merek 2001).

Permohonan sebagaimana dimaksud di atas ditandatangani oleh pemohon atau kuasanya serta dilampiri dengan bukti pembayaran biaya. Pemohon dapat terdiri dari satu orang atau beberapa orang secara bersama ataupun badan hukum. Namun dalam hal permohonan diajukan oleh lebih dari satu pemohon yang secara bersama-sama berhak atas merek tersebut, semua nama pemohon dicantumkan dengan memilih salah satu alamat sebagai alamat mereka. Permohonan ditandatangani oleh salah satu dari pemohon yang berhak atas merek tersebut dengan melampirkan persetujuan tertulis dari para pemohon yang mewakilkan. Apabila permohonan diajukan melalui kuasanya (Konsultan HKI), surat kuasa untuk itu ditandatangani oleh semua pihak yang berhak atas merek tersebut. Adapun biaya yang dikenakan untuk pendaftaran merek adalah sebesar Rp1.000.000 (satu juta rupiah) untuk 1 (satu) kelas barang dengan maksimal 10 (sepuluh) jenis barang.

Tahapan kedua adalah tahapan pemeriksaan. Pada tahapan ini permohonan pendaftaran merek yang telah memenuhi syarat administrasi akan diperiksa secara substantif. Pemeriksaan substantif dilakukan oleh pemeriksa merek untuk mengetahui apakah merek yang hendak didaftarkan ini bertentangan dengan beberapa aturan dalam hal ini adalah Pasal 4, Pasal 5 dan Pasal 6 UU Merek 2001.

Pada Pasal 4 UU Merek 2001 dinyatakan bahwa: "Merek tidak dapat didaftar atas dasar Permohonan yang diajukan oleh Pemohon yang beriktikad tidak baik." Pada dasarnya berdasarkan pasal ini dilarang pendaftaran merek atas iktikad tidak baik. Pada Penjelasan Pasal 4 UU Merek 2001 selanjutnya dinyatakan bahwa pemohon yang beriktikad baik adalah pemohon yang mendaftarkan mereknya secara layak dan jujur tanpa ada niat apapun untuk membonceng, meniru, atau menjiplak ketenaran merek pihak lain demi kepentingan usahanya yang berakibat kerugian pada pihak lain itu atau menimbulkan kondisi persaingan curang, mengecoh, atau menyesatkan konsumen. Sebagai contoh, merek dagang A yang sudah dikenal masyarakat secara umum sejak bertahun-tahun ditiru demikian rupa sehingga memiliki persamaan pada pokoknya atau keseluruhannya dengan merek 
dagang A tersebut. Dalam contoh itu sudah terjadi iktikad tidak baik dari peniru karena setidak-tidaknya patut diketahui unsur kesengajaannya dalam meniru merek dagang yang sudah dikenal tersebut.

Pada Pasal 5 UU Merek 2001 pada intinya dilarang pendaftaran merek yang bertentangan dengan peraturan perundang-undangan dan merupakan merek yang telah menjadi milik umum. Bunyi Pasal 5 adalah sebagai berikut:

"Merek tidak dapat didaftar apabila Merek tersebut mengandung salah satu unsur di bawah ini:

a. bertentangan dengan peraturan perundang-undangan yang berlaku, moralitas agama, kesusilaan, atau ketertiban umum;

b. tidak memiliki daya pembeda;

c. telah menjadi milik umum; atau

d. merupakan keterangan atau berkaitan dengan barang atau jasa yang dimohonkan pendaftarannya."

Pada penjelasan Pasal 5 UU Merek 2001 dijelaskan bahwa:

a. Huruf a, termasuk dalam pengertian bertentangan dengan moralitas agama, kesusilaan, atau ketertiban umum adalah apabila penggunaan tanda tersebut dapat menyinggung perasaan, kesopanan, ketenteraman, atau keagamaan dari khalayak umum atau dari golongan masyarakat tertentu;

b. Huruf $b$, tanda dianggap tidak memiliki daya pembeda apabila tanda tersebut terlalu sederhana seperti satu tanda garis atau satu tanda titik, ataupun terlalu rumit sehingga tidak jelas.

c. Huruf c, salah satu contoh Merek seperti ini adalah tanda tengkorak di atas dua tulang yang bersilang, yang secara umum telah diketahui sebagai tanda bahaya. Tanda seperti itu adalah tanda yang bersifat umum dan telah menjadi milik umum. Oleh karena itu, tanda itu tidak dapat digunakan sebagai Merek.

d. Huruf d, Merek tersebut berkaitan atau hanya menyebutkan barang atau jasa yang dimohonkan pendaftarannya, contohnya Merek Kopi atau gambar kopi untuk jenis barang kopiatau untuk produk kopi.

Selanjutnya pada Pasal 6 UU Merek 2001 dilarang pendaftaran merek yang memiliki persamaan pada pokok atau persamaan pada keseluruhan terhadap merek lain yang telah terdaftar, serta mengatur mengenai pelarangan pendaftaran pada merek terkenal. Pasal 6 berbunyi:

(1) Permohonan harus ditolak oleh Direktorat Jenderal apabila Merek tersebut:

a. mempunyai persamaan pada pokoknya atau keseluruhannya dengan Merek milik pihak lain yang sudah terdaftar lebih dahulu untuk barang dan/atau jasa yang sejenis;

b. mempunyai persamaan pada pokoknya atau keseluruhannya dengan Merek yang sudah terkenal milik pihak lain untuk barang 


\section{dan/atau jasa sejenis;}

c. mempunyai persamaan pada pokoknya atau keseluruhannya dengan indikasi-geografis yang sudah dikenal.

(2) Ketentuan sebagaimana dimaksud pada ayat (1) huruf b dapat pula diberlakukan terhadap barang dan/atau jasa yang tidak sejenis sepanjang memenuhi persyaratan tertentu yang akan ditetapkan lebih lanjut dengan Peraturan Pemerintah.

(3) Permohonan juga harus ditolak oleh Direktorat Jenderal apabila Merek tersebut:

a. merupakan atau menyerupai nama orang terkenal, foto, atau nama badan hukum yang dimiliki orang lain, kecuali atas persetujuan tertulis dari yang berhak;

b. merupakan tiruan atau menyerupai nama atau singkatan nama, bendera, lambang atau simbol atau emblem negara atau lembaga nasional maupun internasional, kecuali atas persetujuan tertulis dari pihak yang berwenang;

c. merupakan tiruan atau menyerupai tanda atau cap atau stempel resmi yang digunakan oleh negara atau lembaga Pemerintah, kecuali atas persetujuan tertulis dari pihak yang berwenang.

Tahapan selanjutnya adalah proses pengumuman. Dalam jangka waktu 3 (tiga) bulan Ditjen HKI akan mengumumkan merek yang hendak didaftarkan melalui berita resmi merek dan biasanya pengumuman ini dilakukan melalui website dgip.go.id. Pada tahapan pengumuman inilah pihak-pihak yang merasa kurang berkenan atas pendaftaran suatu merek dapat mengajukan keberatan. Atas adanya keberatan yang diajukan oleh pihak ketiga maka pihak pemohon pendaftaran merek dapat juga mengajukan sanggahan. Apabila menemui kondisi ini maka Ditjen HKI akan melakukan pemeriksaan kembali atas merek tersebut yang nantinya melalui mekanisme pemeriksaan kembali akan diutuskan apakah pendaftaran atas merek tersebut dapat dilanjutkan atau ditolak. Dalam hal permohonan pendaftaran merek tersebut ditolak, maka pihak pemohon dapat mengajukan banding ke Komisi Banding. Sebaliknya jika pendaftaran merek dianggap dapat diterima maka akan terbit surat persetujuan pendaftaran merek. ${ }^{13}$

Berdasarkan surat persetujuan merek tersebut maka kepada pemohon akan diberikan sertifikat merek sebagai bukti kepemilikan hak atas merek tersebut. Sertifikat merek diberikan kepada orang atau badan hukum yang mengajukan permohonan pendaftaran selambat-lambatnya 30 (tiga puluh) hari sejak merek didaftar di dalam Daftar Umum Merek, Sertifikat merek juga memuat jangka waktu

13 Wawancara dengan Bapak Harianto, S.H. selaku Kepala Subbidang Pelayanan Administrasi Hukum Umum dan Hak Kekayaan Intelektual Kementerian Hukum dan Hak Asasi Manusia Kantor Wilayah D.I. Yogyakarta pada hari Senin, 22 Juni 2015. 
berlakunya merek, yakni menurut ketentuan Pasal 28 adalah 10 (sepuluh) tahun sejak tanggal penerimaan dan dapat diperpanjang. Perpanjangan tersebut dilakukan 12 (dua belas) bulan sebelum berakhirnya jangka waktu merek tersebut dan diperpanjang untuk jangka waktu yang sama yaitu 10 (sepuluh) tahun (Pasal 35).

Sertifikat merek sebagaimana dimaksud merupakan alat bukti resmi bahwa pemilik merek telah memakai merek yang bersangkutan pada tanggal pendaftaran. Kegunaan sertifikat merek sebagai bukti resmi adalah untuk membuktikan dalam suatu perkara tentang merek bahwa merek tersebut telah dipakai, maka pemilik merek dapat memberikan bukti resmi berupa surat pendaftaran tersebut. ${ }^{14}$

Terhadap semua tahapan dalam pendaftaran merek di atas sebenarnya di UU Merek 2001 telah mengestimasi bahwa hanya akan memakan waktu 14 (empat belas) bulan 10 (sepuluh) hari. Akan tetapi pada praktiknya proses dari pendaftaran sampai terbitnya sertifikat merek memakan waktu sekitar 3 (tiga) hingga 4 (empat) tahun. Berdasarkan wawancara yang dilakukan kepada Kepala Subbidang Pelayanan Administrasi Hukum Umum dan HKI Harianto, S.H., keterlambatan proses pelayanan pendaftaran merek adalah dikarenakan minimnya jumlah sumber daya manusia pemeriksa merek. Jumlah pemeriksa merek tidaklah seimbang dengan jumlah permohonan pendaftaran merek yang mencapai ribuan setiap harinya. ${ }^{15}$ Sedangkan faktor lain yang menyebabkan keterlambatan dalam proses pendaftaran merek adalah ketidaksiapan pemohon untuk melengkapi syarat-syarat pendaftaran merek. Contoh sederhananya adalah pada saat proses administrasi, banyak pemohon yang belum mempersiapkan etiket mereknya dengan baik. Pada saat pihak Ditjen HKI meminta pemohon untuk segera melengkapinya dan pihak pemohon tidak segera melengkapi, hal ini membuat proses pendaftaran merek menjadi tertunda.

Berdasarkan pemaparan di atas, pada dasarnya sistem pendaftaran merek di Indonesia secara konsepsi sudah baik. Permasalahan berada pada kurangnya sumber daya manusia pada Ditjen HKI. Kurangnya jumlah sumber daya manusia ini berdampak pada kurang efektif dan optimalnya kinerja Ditjen HKI dalam proses penerimaan permohonan pendaftaran merek sehingga membuat jangka waktu pengurusan hak merek menjadi lebih lama dari waktu yang sudah tercantum pada UU Merek 2001.

\section{E. Praktik Trademark Squatting di Indonesia}

Definisi trademark squatting tidak dapat dijumpai di UU Merek 2001. Hal ini menjadi wajar karena selain trademark squatting adalah hal yang tergolong asing di 
Indonesia, praktik ini juga sebenarnya bersifat semu karena ia tidak terlihat namun ada dan dapat dirasakan.

Trademark squatting dapat ditemukan definisinya dalam WIPO. Intellectual Property Handbook memaknai trademark squatting sebagai "the registration or use of a generally well-known foreign trademark that is not registered in the country or is invalid as a result of non-use". ${ }^{16}$ WIPO menyatakan bahwa trademark squatting adalah tindakan mendaftarkan atau menggunakan merek yang umumnya merupakan merek asing terkenal, di mana merek tersebut belum terdaftar di suatu negara atau merek tersebut sudah terdaftar namun tidak pernah digunakan oleh pemilik merek yang bersangkutan. Definisi juga diberikan oleh Doris Long yang menyatakan trademark squatters sebagai pihak yang berupaya mendaftarkan merek milik pihak lain sebelum merek tersebut didaftarkan oleh pihak pemilik merek yang asli. ${ }^{17}$

Secara praktis trademark squatting dapat diartikan sebagai suatu tindakan yang dilakukan oleh trademark squatters untuk mendaftarkan merek, bisa berupa merek dagang ataupun jasa, milik orang lain yang belum terdaftar untuk kemudian setelah sertifikat kepemilikkan merek tersebut didapatkan akan ia jual kepada pemilik merek yang asli dengan ancaman apabila pemilik merek yang asli tersebut tidak mau membeli maka pemilik merek yang asli harus mengganti merek yang sedang digunakan atau jika tetap berkeras menggunakan maka trademark squatters akan mempersoalkan hal ini melalui jalur hukum.

Ditinjau dari sisi pihak yang menjadi korban, trademark squatting dapat diklasifikasikan menjadi dua, yang pertama adalah korban merupakan pemilik merek luar negeri yang tidak atau belum terdaftar di negara trademark squatters, mengingat sifat pendaftaran merek yang bersifat lokal atau hanya berlaku di negara tempat didaftarkannya merek tersebut. Kedua adalah korban yang merupakan pemilik merek lokal dalam negeri yang mana sudah menggunakan mereknya namun belum terdaftar.

Praktik trademark squatting di luar negeri dapat terlihat di negara Tiongkok. Perusahaan Apple mencoba untuk memasarkan produk terkenalnya yaitu iPhone ke negara Tiongkok yang notabene adalah salah satu pasar terbesar di dunia. Apple sudah melakukan pendaftaran atas merek dagang iPhone kepada Chinese Trademark Office pada tahun 2002. Namun, pihak Apple hanya mendaftarkan merek pada sub kelas 'komputer dan software komputer', tanpa mendaftarkannya pada sub kelas 'telepon dan telepon genggam'. Padahal sebagaimana yang telah

16 World Intellectual Property Organization, WIPO Intellectual Property Handbook, Jenewa: WIPO Publication, 2004, hlm. 90.

17 Doris Estelle Long, "Is Fame All There Is? Beating Global Monopolists at Their Own Marketing Game", George Washington International Law Journal, Volume 40, Number 1, 2008, hlm. 140. 
diketahui, iPhone merupakan produk smartphone yang tergolong sebagai telepon genggam. Segera setelah itu, sebuah perusahaan asal Tiongkok yang bernama Hanwang Technology mendaftarkan merek iPhone di bawah sub kelas termasuk 'telepon dan telepon genggam'. Telah terdaftarnya merek iPhone pada sub kelas 'telepon dan telepon genggam' atas milik Hanwang Technology tentunya memberikan mereka hak untuk melarang Apple menjual produk iPhone di Tiongkok. Apple berjuang keras untuk mendapatkan kembali merek miliknya, namun mereka kalah dalam posisinya di Chinese Trademark Office dan juga pada Trade Mark Review and Adjudication Board (TRAB). Pada akhirnya Apple kemudian bersepakat untuk membayar $\$ 3.650 .000$ kepada Hanwang Technology untuk mendapatkan kembali hak atas merek iPhone di sub kelas 'telepon dan telepon genggam'. ${ }^{18}$

Trademark squatting juga pernah menimpa Starbucks Corporation yang merupakan perusahaan yang core dengan bisnisnya utamanya adalah penjualan kopi dengan membuka gerai. Pada tahun 1997, Starbucks mendaftarkan mereknya di Rusia dan telah mendapat sertifikat hak merek. Namun, Starbucks Corporation tidak pernah membuka bisnisnya di Rusia secara resmi dengan membuka gerai melainkan hanya menjualnya melalui toko-toko kecil saja. Pada tahun 2002, seorang trademark squatters Rusia bernama Sergei Zuikov mendaftarkan merek Starbucks untuk produk kopi kepada The Federal Service for Intellectual Property or Rospatent Rusia setelah sebelumnya mengajukan permohonan pembatalan hak merek Starbucks dengan alasan tidak digunakan. Setelah memiliki hak atas merek Starbucks, Sergei Zuikov menawarkan kepada Starbucks Corporation selaku pemilik sebenarnya atas merek Starbucks di Amerika Serikat untuk membeli hak merek tersebut dengan harga $\$ 600.000$. Starbucks Corporation menolak dan memutuskan untuk membawa perkara ini ke pengadilan dengan mengajukan gugatan pembatalan merek. Pada akhirnya Starbucks dimenangkan dengan alasan Sergei Zuikov mendaftarkan merek dengan iktikad tidak baik. ${ }^{19}$

Permasalahan yang menimpa dua perusahaan besar di atas pada intinya disebabkan oleh sistem pendaftaran merek yang bersifat lokalistik atau tidak berlaku internasional melainkan hanya di negara di tempat didaftarkan saja. Selain itu lemahnya sistem pendaftaran merek di dua negara tempat terjadinya trademark squatting juga menjadi faktor yang membuat praktik ini semakin berkembang. Bagaimana mungkin merek seterkenal iPhone dan Starbucks tidak digolongkan sebagai merek terkenal oleh otoritas HKI di kedua negara tersebut.

\footnotetext{
18 Palo Alto Business Attorney, "Can Apple Solve Its iPhone Trademark Problem in China?", http://dypadvisor.com/2009/07/06/apple-iphone-trademark-china, diakses pada 20 Maret 2015.

19 Kitsuron Sangsuvan, "Trademark Squatting", http://hosted.law.wisc.edu/wordpress/wilj/files2014/01/Sangsuvan final v2.pdf, diunduh pada tanggal 20 Maret 2015.
} 
Sedangkan untuk praktik trademark squatting pada merek lokal atau di Indonesia, hasil penelitian ini belum dapat merekonstruksi secara utuh dan jelas contoh kasus dari praktik trademark squatting di Indonesia. Hal ini dikarenakan memang praktik ini belum marak terjadi di Indonesia, selain itu jikapun praktik ini ada maka itu bersifat semu dan sulit untuk teridentifikasi. Akan tetapi praktik trademark squatting berpotensi tinggi dapat berkembang di Indonesia sebagai dampak sistem perlindungan first to file pada hak merek yang memiliki celah-celah hukum.

Celah yang pertama terlihat jelas pada saat proses administrasi pendaftaran merek. Tidak ada satupun dokumen yang mewajibkan pemohon atau pendaftar merek menyertakan bukti bahwa ia adalah pemilik dan pengguna dari merek yang hendak didaftarkan tersebut. Hal ini menjadi penting karena praktik trademark squatting umumnya terjadi dengan kondisi si trademark squatters tidak menggunakan menggunakan merek yang didaftarkannya tersebut. Memang pada UU Merek 2001 diatur bahwa Ditjen HKI bisa melakukan pencabutan hak atas merek jika dalam waktu 3 (tiga) tahun berturut-turut tidak digunakan sebagaimana diatur dalam Pasal 61 UU Merek 2001. Namun demikian, dalam praktiknya hal ini sangat sulit dilakukan oleh Ditjen HKI. Kekurangan sumber daya manusia dan ketidakadaan data membuat Ditjen HKI kesulitan untuk memverifikasi apakah seorang pemilik sertifikat hak atas merek benar-benar menggunakan merek yang dimilikinya tersebut. ${ }^{20}$

Celah hukum berikutnya adalah terkait pengaturan mengenai merek terkenal. Pada Pasal 6 ayat 1 huruf b UU Merek 2001 sudah dilarang secara tegas atas pendaftaran merek yang terkenal. Permasalahan muncul ketika tidak adanya suatu indikator tegas terkait merek mana yang tergolong sebagai merek terkenal. Pada Penjelasan Pasal 6 ayat 1 huruf b UU Merek 2001 hanya diberikan 3 (tiga) indikator suatu merek itu bisa digolongkan sebagai merek terkenal. Pertama adalah reputasi merek terkenal yang dilakukan dengan promosi secara gencar-gencaran; kedua, investasi di beberapa negara di dunia yang dilakukan oleh pemiliknya; dan yang ketiga adalah adanya bukti pendaftaran merek di beberapa negara. Indikator yang tidak tegas ini kerap menimbulkan multi interpretasi antar pemeriksa merek. Mungkin untuk merek-merek luar negeri yang sudah sangat terkenal hal ini bisa dihindari. Tetapi untuk merek-merek luar negeri yang belum begitu terkenal tentunya pengetahuan mengenai merek-merek internasional antar satu pemeriksa merek dengan pemeriksa merek lainnya tidaklah sama.

Celah hukum juga terdapat pada Pasal 90-91 UU Merek 2001. Pasal-pasal ini memungkinkan pemilik merek dalam hal ini yang sudah mendaftarkan merek dan memiliki sertifikat hak atas merek untuk dapat memidanakan orang atau pihak- 
pihak lain yang menggunakan merek yang dipunyai oleh pemilik hak atas merek. Pasal ini sangat mungkin dijadikan cara oleh trademark squatters untuk mengintimidasi pemilik merek asli yang tidak mau membeli merek yang telah didaftarkan ataupun mengganti merek asli yang selama ini mereka gunakan. Tentu apabila pelaku usaha selaku pemilik merek yang asli tidak memiliki pemahaman terhadap hukum maka mereka akan lebih condong untuk berdamai dengan trademark squatters yaitu dengan cara membeli atau membayar sejumlah uang untuk merek tersebut.

Tindakan yang dilakukan oleh trademark squatters ini mungkin dapat dinilai sebagai tindakan yang curang dan jahat, akan tetapi dari perspektif hukum dalam hal ini UU Merek 2001, apa yang dilakukan oleh trademark squatters adalah upaya untuk mempertahankan apa yang menjadi miliknya. Dalam sistem first to file pada pendaftaran merek jelas mengatur bahwasanya pemilik merek yang sah adalah pemilik yang memiliki sertifikat atas merek tersebut.

Meskipun tidak ada aturan yang melarang secara eksplisit praktik trademark squatting dalam UU Merek 2001, tetapi hal ini bisa sebenarnya dicegah dengan menerapkan aturan Pasal 4 UU Merek yang dinyatakan bahwa merek tidak dapat didaftarkan apabila memiliki iktikad buruk. Tentu dapat kita nilai bahwa trademark squatters mendaftarkan merek yang bukan miliknya untuk kemudian dijual kembali dengan harga yang lebih mahal pada pemilik asli merek tersebut merupakan satu bentuk iktikad tidak baik. Pada realitasnya, sulit sekali untuk mendeteksi pada saat awal pendaftaran seseorang itu apakah ia mendaftarkan merek dengan itikad baik. Pada asasnya Ditjen HKI harus menerima dan menganggap setiap orang yang hendak mendaftarkan merek sebagai orang yang berkitikad baik kecuali dapat dibuktikan sebaliknya. Seorang korban trademark squatting sebenarnya bisa menggunakan Pasal 4 UU Merek 2001 ini untuk menggugat pelaku trademark squatting ke pengadilan niaga. Pada kasus ini adalah terkait dengan iktikad buruknya dalam mendaftarkan merek. Namun demikian, untuk melakukan hal ini tentu pelaku usaha yang menjadi korban haruslah setidaknya paham terhadap hukum dan aturan mengenai merek. Pada konteks ini bisa dikatakan masih banyak pelaku usaha di Indonesia yang belum memiliki pengetahuan yang cukup mengenai hal tersebut.

Pemaparan di atas membuktikan bahwasanya pada tataran praktik sistem pendaftaran merek Indonesia yang berlaku saat ini banyak memiliki celah-celah hukum yang berpotensi dapat dimanfaatkan oleh para pendaftar merek dengan iktikad buruk termasuk di dalamnya para pelaku trademark squatting. Kondisi ini diperburuk dengan lemahnya kesadaran para pelaku usaha khususnya di Indonesia bahwa merek adalah aset penting dalam bisnis mereka dan sudah seharusnya disegerakan pendaftarannya. Selain itu, ketidakpahaman mereka terhadap hukum terkhususnya mengenai merek membuat posisi para pelaku usaha ini kian rawan 
untuk menjadi korban trademark squatting. Lemahnya pemahaman mengenai hukum dan kesadaran terhadap pentingnya pendaftaran merek terlihat dari masih banyaknya pelaku usaha yang terkesan enggan ketika ditawarkan jasa untuk mendaftaran merek. ${ }^{21}$ Kebanyakan mereka beranggapan pendaftaran merek adalah hal yang tidak penting dan membuang-buang uang. Padahal tentu lebih baik menyisihkan sedikit uang untuk mendaftarkan merek ketimbang harus menghadapi risiko menjadi korban kejahatan-kejahatan merek, termasuk di dalamnya trademarksquatting.

Dalam perspektif berbeda tentu perbaikan terhadap proses pendaftaran merek di Indonesia mutlak dibutuhkan. Selain sebagai suatu bentuk perlindungan terhadap merek dalam negeri, tentunya perbaikan sistem ini juga berguna untuk menjamin keberlangsungan investasi dan perdagangan internasional Indonesia. Tanpa disertai sistem pengaturan mengenai merek yang dapat menjamin kepastian hukum bagi merek-merek produk asing tentunya akan dapat membuat investor berpikir ulang untuk masuk ke Indonesia.

\section{F. Konsepsi Ideal Proses Pendaftaran Merek di Indonesia}

Jika berbicara mengenai seperti apa konsepsi ideal pendaftaran merek di Indonesia maka yang mungkin pertama menarik untuk dibahas adalah apakah sistem first to file telah cukup efektif memberikan perlindungan pada pemilik merek. Pada dasarnya sistem first to file hadir guna menciptakan ketertiban dan kepastian hukum dalam proses pendaftaran merek diibandingkan dengan sistem first to use yang dulunya pernah digunakan oleh Indonesia yaitu sekitar tahun 1961. Namun demikian, seperti yang dikatakan sebelumnya bahwa sistem first to file jika tidak diterapkan dengan baik pengawasannya akan dapat memiliki celah hukum untuk disalahgunakan tak terkecuali dalam kasus trademark squatting.

Sistem yang baik untuk digagas adalah first to file based on use. Sistem ini pada pokoknya tetap mempertahankan sistem first to file namun dengan adanya semacam kontrol oleh Ditjen HKI terhadap penggunaan merek tersebut oleh pendaftar merek. Sistem ini menghendaki adanya kewajiban bagi pendaftar merek untuk menunjukkan bahwa ia adalah pemilik merek yang sebenarnya dan tentunya pendaftaran atas merek yang ia lakukan adalah untuk digunakan oleh pemilik merek tersebut.

Perubahan pertama untuk mengakomodir sistem first to file based on use dimulai pada tahapan pemohonan pendaftaran merek. Hendaknya pada proses ini ditambahkan satu syarat dokumen lain yaitu semacam dokumen atau surat keterangan bisa dari RT/RW setempat yang menyatakan bahwa pendaftar merek ini

21 Wawancara dengan Bapak Irawan Harahap, S.H., S.E., M.Kn., CLA. selaku konsultan terdaftar dan pakar Hak Kekayaan Intelektual pada hari Kamis, 18 Juni 2015. 
adalah pemilik yang sah dari merek yang hendak didaftarkan tersebut. Apabila hal ini bisa diterapkan maka ini bisa menjadi upaya awal untuk memutus gerak dari para pelaku trademark squatting. ${ }^{22}$ Selain itu hendaknya sebelum pemohon merek mengajukan permohonan pendaftaran merek mereka diwajibkan untuk menelusuri merek-merek yang sudah terdaftar sebelumnya di website dgip.go.id yang memang sudah disediakan oleh Ditjen HKI. Hal ini sebagai suatu bentuk iktikad baik si pendaftar merek karena ia sudah terlebih dahulu sudah mencari tau apakah suatu merek itu telah terdaftar atau belum.

Perubahan berikutnya yang dapat dilakukan adalah terkait dengan batas waktu 3 (tiga) tahun berturut-turut yang dapat menjadi alasan bagi Ditjen HKI untuk mencabut hak atas merek. Aturan ini hendaknya benar-benar dilaksanakan dengan baik oleh Ditjen HKI dengan mengadakan semacam inspeksi berkala, jika alasannya adalah kekurangan sumber daya manusia, tentu tidak salah ketika lahir wacana untuk menambah jumlah sumber daya manusia di Ditjen HKI itu sendiri. Jika memang tidak bisa dilakukan oleh Ditjen HKI, pengaturan bisa efektif dengan cara memberikan kewajiban pada pemilik sertifikat merek untuk secara berkala melaporkan bahwa ia telah menggunakan merek yang ia daftarkan tersebut. ${ }^{23}$ Sebagai contoh dapat dibuat sebuah regulasi yang mewajibkan pemilik sertifikat merek untuk melaporkan satu atau dua kali dalam rentang waktu 3 (tiga) tahun berturut-turut bahwa ia telah menggunakan merek yang telah ia daftarkan tersebut.

Selain itu terdapat hal lain yang bisa dilakukan oleh Ditjen HKI guna mencegah praktik trademark squatting ini. Hal ini terkait dengan sosialisasi kepada masyarakat terkhususnya pelaku usaha guna menimbulkan kesadaran bahwa merek adalah bagian dari aset mereka. Paradigma yang umum berkembang masyarakat bahwa mendaftar merek itu rumit mahal dan tidak ada manfaatnya haruslah diubah. Keberlangsungan usaha di masa depan serta kemungkinan terhindar dari berbagai kejahatan yang dilakukan oleh pihak-pihak bersangkutan dalam hal ini termasuk di dalamnya trademark squatting haruslah menjadi bahan pertimbangan. Tentunya biaya pendaftaran sejumlah Rp1.000.000 (satu juta rupiah) tidak ada artinya dibandingkan dengan biaya yang akan dikeluarkan jika nanti terkena praktik trademarksquatting.

Teruntuk praktik trademark squatting terhadap produk-produk luar negeri maka upaya yang dapat dilakukan adalah dengan melakukan pembuatan semacam standarisasi yang lebih jelas mengenai klasifikasi terhadap merek-merek terkenal. ${ }^{24}$ Hal ini akan lebih praktis jika Ditjen HKI secara berkala memiliki database terhadap

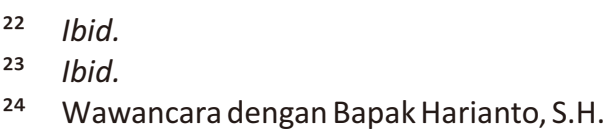


merek-merek terkenal baru. Diharapkan dengan adanya suatu standarisasi terhadap merek terkenal ini, maka multi interpretasi antar para pemeriksa merek terhadap merek mana yang tergolong merek terkenal dan mana yang tidak dapat dikurangi atau bahkan dihilangkan sama sekali.

Upaya lain yang dapat dilakukan adalah dengan mempertimbangkan Indonesia untuk segera meratifikasi Madrid System. Protokol ini pada pokoknya bertujuan untuk memperluas sifat perlindungan merek yang pada awalnya lokalistik menjadi bisa berlaku secara internasional antar sesama negara yang meratifikasi Madrid System hanya dengan melakukan pendaftaran satu kali saja.

Madrid System merupakan dua perjanjian internasional yang di dalamnya diatur mengenai mekanisme pendaftaran merek secara internasional, yaitu The Madrid Agreement Concerning The International Registration of Marks yang ditandatangani tahun 1881 dan mulai berlaku efektif tahun 1892, serta Protocol Relating to The Madrid Agreement 1989 atau yang dikenal sebagai Madrid Protocol yang mulai berlaku efektif tanggal 1 Januari 1995 dan mulai dioperasikan tanggal 1 April 1996. Kedua perjanjian internasional yang dikenal sebagai Madrid System tersebut menyediakan pendaftaran merek, pemeliharaan merek, dan pengaturan merek secara terpusat melalui Internasional Biro (IB) pada WIPO. ${ }^{25}$

Dengan diberlakukannya Madrid System, Indonesia dapat menghindari adanya praktik trademark squatting terutama yang terjadi pada produk-produk luar negeri. Trademark squatting akan dapat terhindari atau setidaknya terminimalisasi karena dengan mendaftar melalui IB pada WIPO secara otomatis berarti merek tersebut terdaftar di seluruh negara yang telah meratifikasi Madrid System.

Ratifikasi terhadap Madrid System akan dapat menciptakan ketenangan bagi pemilik merek asing dari negara yang juga peratifikasi Madrid System untuk masuk dan memasarkan produk-produknya di Indonesia. Pemilik merek yang hendak mendaftarkan merek miliknya cukup menunjuk negara tujuan lain di mana merek tersebut hendak didaftarkan lalu mengajukan permohonan pendaftaran merek internasional ke IB pada WIPO di negara asalnya. ${ }^{26}$ Sistem ini akan dapat meminimalisasi praktik trademark squatting sedari awal karena setiap negara peratifikasi akan memiliki data dan pemahaman sama terkait merek mana yang telah terdaftar. Sehingga para pelaku trademark squatting tidak dapat lagi memiliki celah untuk mendaftarkan merek-merek asing dengan iktikad tidak baik di Indonesia.

Tentunya besar harapan dengan dilakukannya perbaikan-perbaikan pada

25 Irna Nurhayati dan Agustina Merdekawati, “Relevansi Keikutsertaan Indonesia Dalam International Registration of Marks Madrid System Melalui Ratifikasi Madrid Protocol Terhadap Potensi Peningkatan Daya Saing Bangsa Indonesia di Bidang Perdagangan Internasional", Jurnal Mimbar Hukum Universitas Gadjah Mada, Volume 20, Nomor 3, 2009, hlm. 496-497.

26 Dwi Agustine Kurniasih, "2015: Tahunnya Protokol Madrid Bagi Pendaftaran Merek Internasional”, Jurnal Rechtsvinding Badan Pembinaan Hukum Nasional, 2015, hlm. 3. 
sistem pendaftaran merek di Indonesia akan dapat menciptakan suatu sistem perlindungan merek yang lebih optimal. Sehingga di masa yang akan datang praktikpraktik pendaftaran merek dengan iktikad tidak baik seperti trademark squatting dapat diminimalisasi atau bahkan dihilangkan sama sekali dari Indonesia.

\section{G. Penutup}

Berdasarkan pembahasan di atas, kendala yang ditemui dalam proses pendaftaran merek di Indonesia adalah ketidakseimbangan jumlah sumber daya pemeriksa merek dengan jumlah permohonan merek yang mencapai ribuan setiap harinya. Ketidakseimbangan tersebut mengakibatkan keterlambatan dalam proses pendaftaran merek. Hal ini juga mengakibatkan kesulitan bagi pemeriksa merek untuk meneliti apakah permohonan pendaftaran suatu merek tidak melanggar ketentuan mengenai merek terkenal ataupun bukan merupakan merek yang sudah didaftarkan sebelumnya. Selain itu, minimnya jumlah sumber daya manusia juga menyulitkan dalam mengecek apakah pendaftar merek tersebut bukanlah trademark squatters dalam artian si pendaftar benar-benar menggunakan merek yang hendak didaftarkannya.

Trademark squatting dapat diartikan sebagai suatu tindakan yang dilakukan oleh pelaku yang dikenal sebagai trademark squatters untuk mendaftarkan merek, baik itu merek dagang maupun jasa, milik orang lain yang belum terdaftar. Setelah sertifikat kepemilikan merek tersebut didapatkan, pelaku akan menjualnya kepada pemilik merek asli dengan ancaman apabila merek yang asli tidak mau membeli maka pemilik merek yang asli harus mengganti merek yang sedang digunakan, atau jika tetap berkeras maka pelaku akan mempersoalkan hal ini melalui jalur hukum. Praktik ini secara umum dapat terjadi di Indonesia atas akibat dari banyaknya celah hukum dalam proses pendaftaran merek di Indonesia. Selain itu, kurangnya pemahaman masyarakat terhadap hukum serta kurangnya kesadaran atas pentingnya pendaftaran merek membuat pelaku usaha di Indonesia berisiko untuk menjadi korban trademark squatting.

Konsepsi ideal terkait pendaftaran merek di Indonesia dapat diwujudkan dengan menggagas sistem first to file based on use. Sistem ini diharapkan dapat mempersempit ruang gerak pelaku trademark squatting, karena terdapat semacam kontrol oleh Ditjen HKI terhadap penggunaan merek tersebut. Bentuk kontrol dapat dimulai dari tahapan permohonan pendaftaran merek dengan mencantumkan surat pernyataan atau keterangan bahwa pemohon merupakan pemilik sah dari merek yang hendak didaftarkan. Upaya lain yang dapat dilakukan adalah dengan meratifikasi Madrid System untuk memperluas perlindungan merek dari yang awalnya lokalistik menjadi internasional bagi sesama negara yang meratifikasi perjanjian Internasional tersebut. 
Berdasarkan kesimpulan di atas terdapat beberapa saran yang dapat diberikan antara lain:

1. Praktik trademark squatting dapat terjadi baik pada merek lokal maupun merek asing yang akan masuk ke Indonesia, sehingga sebaiknya para pemilik merek tidak menunda untuk mendaftarkan merek miliknya supaya tidak didahului oleh pelaku trademark squatting;

2. Para pelaku usaha hendaknya menyadari bahwa merek adalah salah satu aset mereka yang berharga sehingga harus dilindungi dengan cara didaftarkan; dan

3. Bagi Ditjen HKI agar dapat mengupayakan perbaikan-perbaikan pada sistem pendaftaran merek. Terutama pada hal yang terkait kekurangan sumber daya manusia tentu solusinya adalah dengan melakukan penambahan pegawai agar sistem pendaftaran merek berikut pengawasannya dapat berjalan secara lebih optimal.

\section{Daftar Pustaka}

\section{Buku}

Asian Law Group Pty Ltd, Hak Kekayaan Intelektual Suatu Pengantar, Alumni, Bandung, 2005.

Casavera, 8 Kasus Sengketa Merek di Indonesia, Graha Ilmu, Yogyakarta, 2009.

Djoko Prakoso, Hukum Merek dan Paten Indonesia, Dahara Prize, Semarang, 1999.

Lindsey, Tim (et.al), Hak Kekayaan Intelektual Suatu Pengantar, Alumni, Bandung, 2002.

O.K. Saidin, Aspek Hukum Hak Kekayaan Intelektual (Intellectual Property Rights), Raja Grafindo Persada, Jakarta, 2004.

Rachmadi Usman, Hukum Hak atas Kekayaan Intelektual: Perlindungan dan Dimensi Hukumnya di Indonesia, Alumni, Bandung, 2003.

Suyud Margono, Aspek Hukum Komersialisasi Aset Intelektual, Nuansa Aulia, Bandung, 2009.

World Intellectual Property Organization, WIPO Intellectual Property Handbook, WIPO Publication, Jenewa, 2004.

\section{Dokumen Lain}

Dwi Agustine Kurniasih, “2015: Tahunnya Protokol Madrid Bagi Pendaftaran Merek Internasional", Jurnal Rechtsvinding Badan Pembinaan Hukum Nasional, 2015.

Hukum Online, "Trademark Squatting Bertumbuh di Indonesia", http://www.hukumonline.com/berita/baca/lt512c3348ac839/itrademarksquatting-i--bertumbuh-di-indonesia, diakses pada 19 Maret 2015.

Irna Nurhayati dan Agustina Merdekawati, "Relevansi Keikutsertaan Indonesia Dalam International Registration of Marks Madrid System Melalui Ratifikasi Madrid Protocol Terhadap Potensi Peningkatan Daya Saing Bangsa Indonesia di 
Bidang Perdagangan Internasional", Jurnal Mimbar Hukum Universitas Gadjah Mada, Volume 20, Nomor 3, 2009.

Long, Doris Estelle, "Is Fame All There Is? Beating Global Monopolists at Their Own Marketing Game", George Washington International Law Journal, Washington, Volume 40, Number 1, 2008.

Palo Alto Business Attorney, "Can Apple Solve Its iPhone Trademark Problem in China?",

http://dypadvisor.com/2009/07/06/apple-iphone-trademark-china, diakses pada 20 Maret 2015.

Sangsuvan, Kitsuron, "Trademark Squatting",

http://hosted.law.wisc.edu/wordpress/wilj/files/2014/01/Sangsuvan_final_v 2.pdf, diunduh 20 Maret 2015.

\section{Dokumen Hukum}

Undang-Undang Nomor 21 Tahun 1961 tentang Merek Perusahaan dan Merek Perniagaan.

Undang-Undang Nomor 19 Tahun 1992 tentang Merek.

Undang-Undang Nomor 14 Tahun 1997 tentang perubahan Undang-Undang No. 19

Tahun 1992 tentang Merek.

Undang-Undang Nomor 15 Tahun 2001 tentang Merek.

Keputusan Menteri Kehakiman Republik Indonesia No. M. 02-HC.01 Tahun 1987

tentang Penolakan Permohonan Pendaftaran Merek yang Mempunyai Persamaan dengan Merek Terkenal Milik Orang lain.

Keputusan Menteri Kehakiman RI No. M.03-HC.02.01 Tahun 1991 tentang

Penolakan Permohonan Pendaftaran Merek Terkenal atau Merek yang Mirip Merek Terkenal Milik Orang Lain. 